\title{
Investigation of the Distribution and Expression Level of Pro and Anti- Apoptotic Bax and Bcl-2 in Ovarian Follicles at Different Developmental Stages
}

\author{
Farklı Gelişim Dönemlerindeki Ovaryum Foliküllerinde Pro ve Anti-Apoptotik \\ Bax ve Bcl-2'nin Dağılım ve Ekspresyon Düzeyinin İncelenmesi
}

\author{
Ugur SEKER $^{1}$ (D) Funda ESKI $^{2}(\mathbb{D})$, Serdal KURT $^{3}$ \\ ${ }^{1}$ Harran University, Faculty of Medicine, Department of Histology and Embryology, Sanliurfa/TURKEY \\ 2 Cukurova University, Faculty of Veterinary Medicine, Department of Gynecology and Obstetrics, Adana//TURKEY \\ ${ }^{3}$ Kahramanmaras Istiklal University, Elbistan Vacational School, Department of Veterinary, Kahramanmaras/TURKEY
}

\section{Abstract}

Background: In this study we aimed to investigate the distribution and expression level of pro and anti-apoptotic proteins, Bax and $\mathrm{Bcl}-2$, in different developmental stages of ovarian follicles and any relations between these proteins and follicle atresia.

Materials and Methods: For that purpose, bilateral 16 ovaries of adult 8 mice were received and the tissues were fixed in $10 \%$ neutral buffered formalin. Routine tissue processing protocol was performed and the samples were embedded into paraffin blocks. Five $\mu \mathrm{m}$ thick sections were received and the tissue sections were stained with Bax and Bcl-2 immunohistochemistry. The ovarian follicles were classified as primordial, primary, secondary and antral. Distribution and expression levels of $\mathrm{Bax}$ and $\mathrm{Bcl}-2$ were evaluated among and within the developmental stages. The expression levels of $\mathrm{Bax}$ and $\mathrm{Bcl}-2$ were also compared with atretic follicle ratio. Results: Immunopositivity of Bax and Bcl-2 were observed in ovarian stromal cells, granulosa, oocytes, and lutheal cells in a varying range. Despite of some immunpositivity, most of the primordial and primary follicle granulosa cells and oocytes were negative for these apoptosis regulator proteins. The intensity of immunopositivity increased at the farther developmental process in follicles. In addition, the immunoexpression level significantly increased just with the beginning of the secondary follicular stage and the expression levels were the most intense in antral follicles. Furthermore, some of the antral follicles were intense Bax positive which were observed with atretic follicle morphology.

Conclusions: Bax and $\mathrm{Bcl}-2$ are crucial regulators in ovarian follicle development. Although $\mathrm{Bcl}-2$ contributes on follicular development, correlation analyses of this study indicated that Bax is a stronger decision marker than $\mathrm{Bcl}-2$ for the fate of ovarian follicle.

Key Words: Bax, Bcl-2, Ovary, Follicle, Atresia

öz.

Amaç: Bu çalışmada, farklı gelişimsel evredeki ovaryum foliküllerinde Bax ve $\mathrm{Bcl}-2$ ekspresyon düzeylerini ve bu proteinlerle folikül atrezisi arasındaki ilişkiyi araştırmayı amaçladık.

Materyal ve Metod: Bu amaçla 8 fareye ait bilateral toplam 16 ovaryum toplandı ve dokular 10\%'luk tamponlanmış formalin içerisinde fikse edildi. Dokulara rutin doku takibi protokolü uygulandı ve örnekler parafin bloklara gömüldü. Parafin bloklara gömülü doku örneklerinden alınan $5 \mu \mathrm{m}$ kalınlığındaki kesitler Bax ve Bcl-2 immunohistokimya boyandı. Ovaryum folikülleri primordiyal, primer, sekonder ve antral şeklinde sınıflandırıldı. Gelişim aşamalarının içinde ve aşamalar arasındaki Bax ve Bcl-2 dağılımı ve ekspresyon düzeyi değerlendirildi. Ekspresyon düzeyleri aynı zamanda folikül atrezisi ile kıyaslandı.

Bulgular: Ovaryum stroma hücrelerinde, granuloza, oosit ve luteal hücrelerde Bax ve Bcl-2 immunopozitivitesi değişen oranlarda izlendi. Yer yer gözlenen immunopozitiviteye karşın, primordiyal ve primer folikül granuloza hücreleri ve oositleri büyük bir oranda apoptozis düzenleyici proteinler yönünden negatifti. İmmunopozitivite yoğunluğu ileri gelişim dönemlerinde artış eğilimindeydi. Ayrıca, immunoekspresyon düzeyi sekonder foliküler aşamadan sonra önemli bir artış gösteriyordu ve antral foliküllerde en yüksek düzeyde ekspresyon yoğunluğu izlendi. Dahası bazı antral foliküllerdeki yoğun Bax pozitifliğine atretik folikül morfolojisi eşlik etmekteydi.

Sonuç: Bax ve Bcl-2 ovaryum folikül gelişiminin önemli düzenleyicileridir. Her ne kadar $\mathrm{Bcl}-2$ gelişim sürecinde etkili olsa da, korelasyon analizleri Bax'ın folikül atrezi veya gelişim kararını vermede Bcl-2'den daha güçlü olduğunu göstermiştir.

Anahtar kelimeler: Bax, Bcl-2, Ovaryum, Folikül, Atrezi
Corresponding Author / Sorumlu Yazar

Dr. Ugur SEKER

Harran Universitesi, Tip Fakultesi, Histoloji ve Embriyoloji Anabilim Dali, Osmanbey Kampüsü, 63000, Haliliye, Sanliurfa/TURKEY

E-mail: seker.ugur.tr@gmail.com

Received / Geliş tarihi: 15.09.2021

Accepted / Kabul tarihi: 01.11.2021

DOI: 10.35440/hutfd.995512 


\section{Introduction}

Due to having functions such as hormone secretion and expelling oocyte, the ovaries are considered as both endocrine and exocrine organs (1). Females born with approximately 2 million primordial follicles and the follicles keep dormant until puberty with the contribution of Anti-Müllerian hormone and phosphatidylinositol 3-kinase/protein kinase $B(P I 3 K / A k t)$ signaling pathway $(2,3)$. Each month during the reproductive lifespan one of these follicles reaches to the end of the developmental stages, the ovulation. In literature, the follicles are divided into three groups according to their gonadotropin dependency. The first and the second groups are partially gonadotropin independent, but the third group contains follicle recruitment, selection, and ovulation under the regulation of gonadotropins, folliclestimulating hormone and luteinizing hormone). In recent years it was identified that intra-ovarian paracrine and autocrine regulators (cytokines, growth factors etc.) are contributing on follicular development or elimination (4-6). Beside of the selected dominant follicle, rest of the simultaneously growing follicles undergo follicle atresia with programmed cell death (7). Programmed cell death (apoptosis) is a cellular death process which is controlled by the cell itself, unlike the uncontrolled cell death in necrosis. Apoptosis is regulated by involvement of numerous genes, some of which regulate cell vitality and proliferation, but the others activate apoptosis or the other sub-types of programmed cell death (pyroptosis or autophagy) $(8,9)$. The most well identified apoptotic cell death processes are arranged by intrinsic (mitochondrial) and extrinsic (receptormediated) signaling pathways. The key regulators of intrinsic apoptotic signaling pathway are Bcl2 associated X (Bax) and $\mathrm{B}$-cell lymphoma 2 ( $\mathrm{Bcl}-2$ ) proteins which are two members of $\mathrm{Bcl}-2$ superfamily (10). Bax and $\mathrm{Bcl}-2$ are classified in pro-apoptotic and anti-apoptotic protein groups respectively. Even though, the current literature provides information on the relationship between apoptosis and the follicle atresia, the underlying mechanism hasn't been fully defined yet. For that reason we aimed to investigate the distribution and expression levels of Bax and $\mathrm{Bcl}-2$, in distinct developmental stages and atretic ovarian follicles.

\section{Materials and Methods}

\section{Experimental design and tissue processing}

All experimental procedures of this study were performed with the approval of Experimental Animal Ethics Committee of Adana Veterinary Control Institute (approval no: 2021-1/522). Ovaries of 8 mice were bilaterally obtained and totally 16 ovaries were fixed in $10 \%$ formalin. The fixed tissue samples were washed under tap water and dehydrated through increasing alcohol series. The samples were cleared in two series of Xylene and embedded into paraffin blocks.

Five $\mu \mathrm{m}$ thick sections were obtained from paraffin blocks with a rotary microtome and immunohistochemistry of Bax and $\mathrm{Bcl}-2$ performed.

\section{Immunohistrochemistry}

Tissue sections were deparaffinized in two series of Xylene and re-hydrated through decreasing alcohol concentration series for 5 minutes in each. The samples rinsed in distilled water and brought to the phosphate buffered saline (PBS). Aldehyde bindings between the epitopes of antigens were removed with the antigen retrieval process which is performed in citrate buffer $(\mathrm{pH} \mathrm{6.0)}$ on a hot plate. Tissue sections were cooled to the room temperature and rinsed in two series of PBS. Endogenous peroxidase activity was blocked with incubating the samples in $3 \% \mathrm{H}_{2} \mathrm{O}_{2}$ that dissolved in methanol. Non-specific binding of antibodies was blocked via incubating the samples with Ultra $V$ Block (Thermo Scientific, Waltham, MA, USA. cat no: TP-125-UB) at room temperature for 7 minutes. After blocking steps, 1:300 diluted antibodies of Bax (Santa Cruz Biotechnology, Dallas, Texas, USA. cat no: sc-7480) and Bcl-2 (Santa Cruz Biotechnology, Dallas, Texas, USA. cat no: sc-7382) were dropped on the sections. Antibody incubation performed in a humidified chamber at $+4^{\circ} \mathrm{C}$ for overnight. The subsequent steps of the immunohistochemistry were performed with a ready to use kit of UltraVision Plus Large Volume Detection System Anti-Polyvalent, HRP (Thermo Scientific, Waltham, MA, USA. cat no: TP-125-HL) and all steps were performed according to the manufacturer's instructions. 3,3'-Diaminobenzidine (DAB) chromogen used for the development of signals and the reaction monitored under a light microscope. Sections were counter stained with hematoxylin and mounted with entellan. Immunohistochemistry stained sections were visualized under a camera attached light microscope (Carl Zeiss Microscopy, GmbH, Germany) and the micrographs were captured.

\section{Classification of the ovarian follicles}

The ovarian follicles were classified as primordial, primary, secondary and antral. The classification performed with the criteria of Sonigo et al. as identified previously (11). The follicles were considered as primordial if surrounded by single layer flattened granulosa cells, and the follicles were primary if the flattened granulosa cells were transformed into cuboidal shape. When the granulosa cells were with two or more layer then the follicles were considered as secondary. The follicles with multi layered granulosa cells were classified as antral if an obvious antral cavity observed. Besides of the developmental classification, the ovarian follicles were classified as atretic or developing depend on the nuclei shape. The follicles were accepted as atretic if granulosa nuclei and/or the oocyte nuclei were pyknotic. In other cases follicles were accepted as healthy and developing.

\section{Quantification of immunohistochemistry}

The immunohistochemistry samples were scored with $h$ score intensity. Scoring performed with the criteria as follows; granulosa cells and oocyte were totally negative (0), mild immunopositivity in granulosa cells and oocyte (1), 
immunopositivity in granulosa cells and low or mild immunopositivity in oocyte (2), dense immunopositivity in granulosa and mild or dense positivity in oocyte (3). Randomly selected 14 follicles of each developmental stage were analyzed under criteria as described above. The obtained scores were recorded and besides the distinct Bax and $\mathrm{Bcl}-2$ scoring, $\mathrm{Bax} / \mathrm{Bcl}-2$ ratio was manually calculated. When the score were 0 for both Bax and $\mathrm{Bcl}-2$ the ratio accepted as null. All obtained data were analyzed statistically.

\section{Statistical analyses}

Due to limited sample size it was determined to use nonparametric Kruskal Wallis test to perform statistical analyses. Multiple comparisons performed with Tamhane's T2 test. The correlations among the $\mathrm{Bax} / \mathrm{Bcl}-2$ ration, Bax expression level, $\mathrm{Bcl}-2$ expression level, and follicle atresia were considered with one-tailed Sperman's Correlation analysis. Results were expressed as mean \pm SD and $p<0.05$ considered as significant.

\section{Results}

\section{Immunohistochemistry results}

Representative micrographs of $\mathrm{Bax}$ and $\mathrm{Bcl}-2$ immunohistochemistry were shown in Figure 1 and 2.

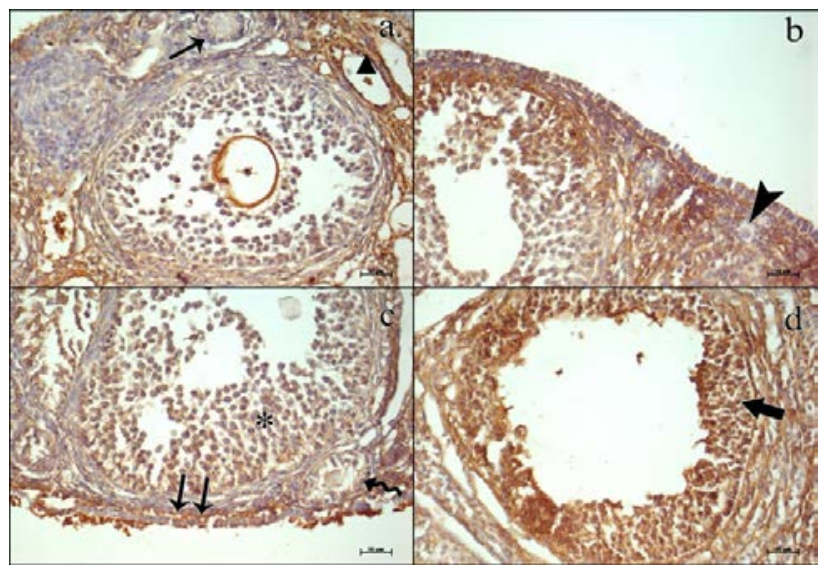

Figure 1. Bax immunohistochemistry in ovarian follicles. a \& b; Immunonegative or very low immunoexpression of Bax in granulosa cells of primordial (arrow head) and primary (arrow) follicles. A secondary follicle with intense Bax positivity (triangle) that undergoes to atresia as observed with pyknotic granulosa and oocyte nuclei. c; Developing secondary (curved arrow) and antral (asterix) follicles with slight Bax immunopositivity. Dense Bax immunopositivity in germinal epithelium (double arrow). d; Atretic antral follicle with dense Bax immunopositivity (thick arrow). Staining: Bax immunohistochemistry. Bar: $50 \mu \mathrm{m}$.

Immunohistochemistry observations indicated that both $\mathrm{Bax}$ and $\mathrm{Bcl}-2$ were expressed in ovarian tissue in a varying intensity. Positivity was observed in germinal epithelium, stromal cells, theca, and granulosa cells, even oocytes. Although observed weak signaling, most of the primordial follicle granulosa cells were immunonegative for both Bax and $\mathrm{Bcl}-2$. Immunopositivity intensity of Bax increased with the formation of antral cavity, but increase in Bcl-2 expression was observed just after the primary/secondary phases and dramatically increase was observed in antral follicles. In addition we observed increased Bax positivity in granulosa cells of some antral follicles. In some follicles, the granulosa cells were observed with pyknotic nuclei and dense Bax immunopositivity. Bax intensity in these follicles indicated the relationship between increased Bax expression and follicle cell nuclei pyknosis. When we consider theca cells, the follicles with less Bax immunopositivty were observed with low theca immunopositivity.

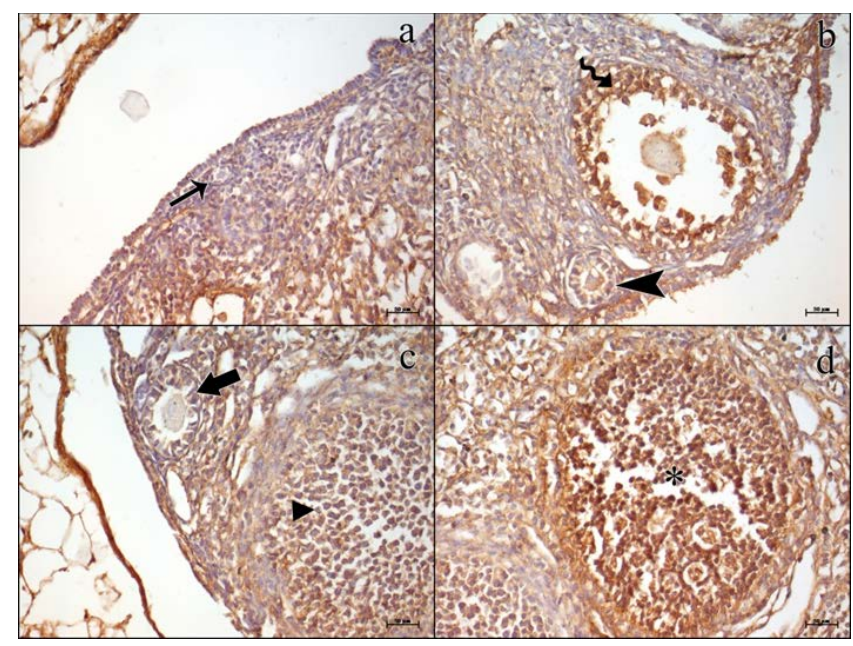

Figure 2. Bcl immunohistrochemistry in ovarian follicles. a; Low immunoexpression in primordial follicle granulosa cells (arrow). b; Slight immunopositivity in primary and dense immunopositivity in antral follicle granulosa cells (curved arrow). c; Mild immunopositivity in secondary (thick arrow) follicle and antral follicle with pyknotic granulosa cell nuclei (triangle). d; Dense immunpositivity in antral follicle (asterix). Staining: Bcl-2 immunohistochemistry. Bar: $50 \mu \mathrm{m}$.

\section{Statistical analyses results}

$\mathrm{Bax}$ and $\mathrm{Bcl}-2$ immunoexpression scores were the lowest in primordial follicles when compared with the other follicle phases. During follicle development, the Bax expression intensity hasn't changed until the antral phase, but Bax expression score of antral follicle was significantly higher than primordial and primary follicles $(p<0.01)$. However, the increase in Bcl-2 immunoexpression level was observed at earlier stages of follicular development. Increased expression score in secondary phase was significantly different than primordial follicle phase $(p<0.01)$ but it was similar to the primary stage $(p>0.05)$. The score result of $\mathrm{Bcl}-2$ in primary follicle was similar $(p>0.05)$ to the both primordial and secondary follicles. The scoring result of secondary follicles was similar $(p>0.05)$ to the primary and antral phases, but antral follicle score was significantly higher than primordial and primary follicles $(p<0.01)$.

$\mathrm{Bax} / \mathrm{Bcl}-2$ ratio in primordial, primary and secondary follicles was similar $(p>0.05)$. The ratio in antral follicles was the highest but there weren't any significantly difference ( $p$ 
$>0.05$ ) among the antral, secondary and primary follicles. The difference between primordial and antral follicles for $\mathrm{Bax} / \mathrm{Bcl}-2$ ratio was significantly different $(\mathrm{p}<0.05)$ (Table 1). When we consider relationship among $\mathrm{Bax} / \mathrm{Bcl}-2$ ratio, Bax expression level and $\mathrm{BCl}-2$ expression with follicle atresia, there was a significant correlation $(p<0.01)$. Furthermore, correlation analyses indicated that the correlation between Bax and follicle atresia was stronger than Bcl2 and follicle atresia. Results of the correlation coefficient analyses were shown in Table 2.

Table 1. Statistical results of immunohistochemistry analyses. Different superscripts on each data demonstrate significantly difference between groups

\begin{tabular}{|c|c|c|c|c|}
\hline Bax & $0.50 \pm 0.76^{a}$ & $0.79 \pm 0.80^{\mathrm{a}}$ & $1.07 \pm 0.73^{\mathrm{ab}}$ & $1.86 \pm 0.77^{b}$ \\
\hline $\mathrm{Bcl}-2$ & $0.43 \pm 0.65^{c}$ & $0.86 \pm 0.86^{\mathrm{cd}}$ & $1.43 \pm 0.51^{\mathrm{de}}$ & $2.00 \pm 0.68^{\mathrm{e}}$ \\
\hline Bax/Bcl-2 ratio & $0.29 \pm 0.61^{f}$ & $0.39 \pm 0.59^{f g}$ & $0.82 \pm 0.64^{\mathrm{fg}}$ & $1.12 \pm 0.78^{g}$ \\
\hline
\end{tabular}

$.^{a-b} p<0.01,{ }^{c-d e} p<0.01,{ }^{c-e} p<0.01,{ }^{c d-e} p<0.01,{ }^{f-g} p<0.05$.

Table 2. Spearman correlations coefficients among Bax, Bcl-2 scores, Bax/Bcl-2 ratio, and the follicle atresia analyses

\begin{tabular}{lcccc}
\hline Bax expression & - & $.551^{* *}$ & $.854^{* *}$ & $.777^{* *}$ \\
Bcl-2 expression & $.551^{* *}$ & - & $.483^{* *}$ & $.267^{*}$ \\
Bax/Bcl-2 ratio & $.854^{* *}$ & $.483^{* *}$ & - & $.669^{* *}$ \\
Follicle atresia & $.777^{* *}$ & $.267^{*}$ & $.669^{* *}$ & - \\
\hline
\end{tabular}

${ }^{*}$ Correlation is significant at the 0.05 level (1-tailed), ${ }^{* *}$ Correlation is significant at the 0.01 level (1-tailed)

\section{Discussion}

Folliculogenesis is a complicated cyclic developmental process of reserve primordial follicles to primary, secondary and antral follicle phases respectively which is regulated by pituitary gonadotropins and intra-ovarian paracrine regulators (12). Follicles either develop until ovulation or regress with a controlled regulatory process of atresia and approximately $99.99 \%$ of the developing follicles are eliminated in a female reproductive lifespan (13). The fetal precursors of oocytes are the germ cells and the total number of germ cells reaches to maximum number 4-5 months after conception, and apoptotic oocyte precursors can be detect at 13 th week of gestation $(14,15)$. Previously published researches indicated that granulosa cells of atretic follicles are overexpressing Fas receptor (16). Overexpression of Fas is probably a cellular response to Fas ligand (FasL) thus induction of extrinsic apoptotic signaling pathway. Fas/FasL knock out animal studies indicated involvement of extrinsic apoptotic signaling pathway in follicular elimination process during ovarian cycle. Also it has been reported that Fas/FasL deficiency results with increase in number of abnormal secondary follicles (17). These findings confirm contribution of apoptosis during follicle atresia. In addition, Fas and FasL regulated extrinsic apoptosis was also identified in luteolysis (18). In literature review we reached very limited studies that are investigating the relationship between follicle atresia and intrinsic apoptotic regulators. However, in one of these Gursoy et al. investigated the distribution and expression levels of $\mathrm{Bax}$ and $\mathrm{Bcl}-2$ in non-atretic rat ovarian follicles of newborn, one month old and adult rats (19). Results of this study indicated that both of the Bax and Bcl-2 were not expressed in oocytes and granulosa cells of primordial follicles. The authors also reported a linear increase in $\mathrm{Bax}$ and $\mathrm{Bcl}-2$ expression at granulosa cells and oocytes during developmental stages. When we compare results of this study we observed some similarity but our results not only demonstrating expression and the distribution of Bax and $\mathrm{Bcl}-2$ in developing healthy follicles but also indicate possible contribution of intrinsic apoptotic regulators during follicular atresia. One of the most similarities between two studies is negative or slight expression of both Bax and $\mathrm{Bcl}-2$ at the granulosa and oocytes in the primordial follicles. Our results also confirm increase in expression during follicular development process in healthy follicles. Furthermore, we have observed that besides of follicle development increased $\mathrm{Bax}$ and $\mathrm{Bcl}-2$ has correlation with follicle atresia. The correlation between Bax expression and follicle atresia was stronger than the correlation between Bcl-2 expression and follicle atresia. For that reason we believe that both of the Bax and $\mathrm{Bcl}-2$ expression is a crucial checkpoint for follicle atresia, but the Bax determines the fate of follicle.

Ethical Approval: All experimental procedures of this study were performed with the approval of Experimental Animal Ethics Committee of Adana Veterinary Control Institute (approval no: 20211/522).

\section{Author Contributions:}

Concept: U.S., F.E., S.K.

Literature Review: U.S., S.K.

Design : U.S., F.E., S.K.

Data acquisition: U.S.

Analysis and interpretation: U.S., S.K.

Writing manuscript: U.S., S.K.

Critical revision of manuscript: F.E.

Conflict of Interest: The authors declare there is no conflict of interest

Financial Disclosure: This study did not received any financial support 


\section{References}

1. Treesh S,Khair N. Effect of thyroid disorders on the adult female albino rats (Histological and Histochemical Study). J Cytol Histol. 2014;5(4):1.

2. Carlsson IB, Scott JE, Visser J, Ritvos O, Themmen A, Hovatta O. Anti-Müllerian hormone inhibits initiation of growth of human primordial ovarian follicles in vitro. Hum Reprod. 2006;21(9):2223-2227.

3. Hsueh AJ, Kawamura K, Cheng Y,Fauser BC. Intraovarian control of early folliculogenesis. Endocr Rev. 2015;36(1):124.

4. Kumar TR, Wang Y, Lu N,Matzuk MM. Follicle stimulating hormone is required for ovarian follicle maturation but not male fertility. Nat Genet. 1997;15(2):201-204.

5. Orisaka M, Miyazaki Y, Shirafuji A, Tamamura C, Tsuyoshi H, Tsang BK, et al. The role of pituitary gonadotropins and intraovarian regulators in follicle development: A mini-review. Reprod Med Biol. 2021;20(2):169-175.

6. Rajkovic A, Pangas SA,Matzuk MM. Follicular development: mouse, sheep, and human models. Knobil and Neill's physiology of reproduction. 2006;1:383-424.

7. Yu YS, Sui HS, Han ZB, Wei L, Luo MJ,Tan JH. Apoptosis in granulosa cells during follicular atresia: relationship with steroids and insulin-like growth factors. Cell Res. 2004;14(4):341-34.

8. D'Arcy MS. Cell death: a review of the major forms of apoptosis, necrosis and autophagy. Cell Biol Int. 2019;43(6):582592.

9. Xia X, Wang X, Cheng Z, Qin W, Lei L, Jiang J, et al. The role of pyroptosis in cancer: pro-cancer or pro-"host"? Cell Death Dis. 2019;10(9):1-13.

10. Brunelle JK, Letai A. Control of mitochondrial apoptosis by the Bcl-2 family. Journal of cell science. 2009;122(4):437441.

11. Sonigo C, Jankowski S, Yoo O, Trassard O, Bousquet N, Grynberg $\mathrm{M}$, et al. High-throughput ovarian follicle counting by an innovative deep learning approach. Sci Rep. 2018;8(1):19.

12. Costa L, Moreia-Pinto B, Felgueira E, Ribeiro A, Rebelo I,Fonseca B. The major endocannabinoid anandamide (AEA) induces apoptosis of human granulosa cells. Prostaglandins, Leukotrienes and Essential Fatty Acids. 2021:102311.

13. Monniaux D, Cadoret V, Clément F, Tran RD, Elis $S$, Fabre $S$, et al. Folliculogenesis, In: Huhtaniemi I, Martini L, eds. Encyclopedia of Endocrine Diseases. Netherlands: Elsevier, 2018:1-22.

14. Vaskivuo TE, Anttonen M, Herva R, Billig Hk, Dorland M, te Velde ER, et al. Survival of human ovarian follicles from fetal to adult life: apoptosis, apoptosis-related proteins, and transcription factor GATA-4. J Clin Endocrinol Metab. 2001;86(7):3421-3429.

15. Rolaki A, Drakakis $P$, Millingos $S$, Loutradis D,Makrigiannakis $A$. Novel trends in follicular development, atresia and corpus luteum regression: a role for apoptosis. Reprod Biomed Online. 2005;11(1):93-103.

16. Hakuno N, Koji T, Yano T, Kobayashi N, Tsutsumi O, Taketani $Y$, et al. Fas/APO-1/CD95 system as a mediator of granulosa cell apoptosis in ovarian follicle atresia. Endocrinology. 1996;137(5):1938-1948.

17. Sakamaki K, Yoshida H, Nishimura Y, Nishikawa SI, Manabe $\mathrm{N}$,Yonehara S. Involvement of Fas antigen in ovarian follicular atresia and luteolysis. Mol Reprod Dev. 1997;47(1):11-18.

18. Roughton SA, Lareu RR, Bittles AH,Dharmarajan AM. Fas and Fas ligand messenger ribonucleic acid and protein expression in the rat corpus luteum during apoptosis-mediated luteolysis. Biol Reprod. 1999;60(4):797-804.

19. Gürsoy E, Ergin K, Başaloğlu H, Koca $Y$,Seyrek K. Expression and localisation of $\mathrm{Bcl}-2$ and $\mathrm{Bax}$ proteins in developing rat ovary. Res Vet Sci. 2008;84(1):56-61. 